\title{
A lakhatási körülmények hatása a mentális egészségre
}

\author{
The impact of housing conditions on mental health
} Szerzők: $\quad$ Puskás Éva, Kormos-Krakkó Ágnes $₫$, Csieklinszki Zsanett, Nagy Beáta Magda
Nemzeti Népegészségügyi Központ, Budapest

Beküldve: 2020. 04. 22.

doi: $\quad$ 10.24365/ef.v61i2.585

\begin{abstract}
Összefoglaló: A lakhatás az alapvető emberi jogok közé tartozik, ám ez nemcsak a fedélhez jutás szükségletét jelenti, hanem minőségi szempontot is, a megfelelő lakhatáshoz (adequate housing) való jogot szintén magában foglalja. Utóbbi - bár konkrét tartalma a földrajzi és szociokulturális különbségekkel együtt változó lehet - a birtoklás zavartalanságát, a megfizethetőséget, a lakhatóságot, az alapvető felszereltséget, valamint az elhelyezkedés szempontjából és kulturális értelemben vett megfelelőséget jelenti. A lakhatási körülmények befolyásolják a jóllétet, a fizikai és mentális egészséget, és így a produktivitást (munkában, oktatásban való részvételt) is.

Áttekintő közleményünk célja a lakhatási körülmények és a mentális egészségmutatók összefüggéseinek bemutatása, a lakhatással kapcsolatos és a mentális egészségre közvetlen és közvetett hatást gyakorló tényezők leírása nemzetközi szakirodalmi adatok felhasználásával.

Kulcsszavak: lakhatás; lakókörnyezet; mentális egészség; épített környezet
\end{abstract}

Summary: The right to housing is a basic human right. However, it does not only entail a right to shelter, but also includes the element of a quality standard: the right to adequate housing. Though the definition of 'adequate' may vary based on geographical and sociocultural differences, it generally entails security, habitability, affordability, availability, basic facilities and equipment, and being adequate from a geographical and cultural perspective. The quality of accommodation impacts psychological and physical well-being, therefore influences productivity at work or in education.

The objective of our review is to explore the relationship between the quality of housing conditions and quality of mental health, as well as the identification of direct and indirect, housing-related factors influencing mental health, based on the currently available research.

Keywords: housing; neighbourhood environment; mental health; built environment

\section{BEVEZETÉS}

A bio-pszicho-szociális modell térnyerése óta evidenciaként kezelik az egészségtudományok, hogy az egészség megőrzése és a megbetegedések jelentős része nem érthető meg azok nélkül az egymással is kölcsönhatásba lépő társas-társadalmi és pszichés tényezők nélkül, amelyek az egyes ember életének - a szúken vett testi, fizikai létezéshez képest - tágabb kontextusát jelentik. ${ }^{1}$
Mégis, amikor a mentális egészséget meghatározó tényezőkre gondolunk, elsősorban az egyéni biológiai, pszichológiai, családi, közösségi vagy kulturális jellemzőket vesszük számba, és kevésbé foglalkozunk a szociális meghatározók (social determinants) azon csoportjával, amelyek nem annyira az interperszonális környezetre, mint inkább azokra a körülményekre vonatkoznak, ahol és ahogyan az emberek élnek és dolgoznak. ${ }^{2}$ 
Miközben - az orvostudomány és az egészségügyi ellátórendszerek fejlődésével - a modern társadalmakban jelentős, pozitív irányú változások mutatkoznak az egészségi állapot mutatóiban (pl. a születéskor várható élettartam növekedése), azoknak a társadalmi helyzettel való összefüggése is egyre kifejezettebb. $^{3}$ Egyes szociodemográfiai, illetve társadalmi-gazdasági tényezők (pl. iskolázottság, jövedelmi viszonyok, foglalkozási kockázatok) jelentősen befolyásolják az életmódot és az egészségügyi ellátáshoz való hozzáférést, így azok az egészségi állapot szintjén jelentkező társadalmi egyenlőtlenségek hátterében is állhatnak. ${ }^{4,5}$ E tényezők hatása lehet közvetlen (pl. az anyagi lehetőségek befolyása a lakóhelyválasztásra), de közvetett, vagyis a szubjektív átélésen/ megítélésen keresztül ható is. Hazai vonatkozásban gondolhatunk itt a Kopp Mária nevével fémjelzett országos reprezentatív vizsgálatokra, amelyek bizonyították, hogy a kedvezőtlenebb szociálisgazdasági helyzet, illetve a lemaradás szubjektív megélése magasabb megbetegedési arányokkal jár együtt, elsősorban a depressziós lelkiállapot közvetítésének révén. ${ }^{6}$

Braveman és munkatársainak modellje szerint a gazdasági és szociális lehetőségek és errőforrások (upstream tényezők) azok az alapvető okok, amelyek a lakhatási és munkakörülmények (downstream tényezők) befolyásolásán át meghatározzák egyrészt az egészségügyi ellátást (annak minőségét, igénybevételét, hozzáférhetőségét stb.), másrészt az egyén egészséggel összefüggő viselkedéseinek és döntéseinek összességét is, amely két tényezőcsoport az egyén egészségi állapotának legfontosabb determinánsa. ${ }^{7}$

A továbbiakban a magyarországi lakáshelyzet főbb jellemzőinek bemutatása után, a mentális egészség szociális meghatározói közül a lakhatás, az otthon és az azt övező élettér befolyásoló szerepére vonatkozó nemzetközi szakirodalmak eredményeit tekintjük át. Elemzésünk során kiindulópontként a környezetpszichológia alapvetését használjuk, amely szerint „a fizikai környezet a viselkedés folya- matában az ember egyenrangú társa, partnere, amely a belső, lélektani folyamatokkal együtt, azokkal kölcsönhatásban (tranzakcióban) vesz részt a viselkedés folyamatában". 8 (2. o.)

Terjedelmi korlátok miatt nem térünk ki minden egyes tényező esetén annak a szocioökonómiai státusszal, jövedelmi viszonyokkal és társadalmi rétegzettséggel való összefüggésére, de premisszaként kezeljük, hogy e jellemzők elsődlegesen befolyásolják a lakóhely megválasztását és használatát, beleértve annak minőségi jellemzőit és a tágabb lakókörnyezet (környék) sajátosságait is. A deprivációból fakadó mentális egészségromlást ez esetben a lakhatás elégtelenségéből fakadó hatások tovább mélyíthetik, amelyek - például a kialakuló munkaképesség-csökkenés vagy a munkahely elvesztése révén - az amúgy is nehéz gazdasági és szociális helyzet további romlását eredményezhetik.

\section{Lakáshelyzet Magyarországon}

A magyar lakásállomány komfort szerinti összetétele folyamatosan javul, a Mikrocenzus 2016-os adatai szerint 93,2\% tartozik a komfortos vagy összkomfortos kategóriába. ${ }^{9} \mathrm{Az}$ ország lakásállományának 6,8\%-a (301 ezer lakás) ugyanakkor félkomfortos, komfort nélküli vagy szükséglakás, vagyis a hazai lakásállománynak továbbra is van egy, a minőséget tekintve a többitől „leszakadt” része.

Nem elfogadhatóak a szubstandardi lakások - amelyekben jellemzően alacsony jövedelmű családok élnek -, legnagyobb arányban a kistelepüléseken, leginkább a községekben fordulnak elő (az 1000 fő alatti településeken minden ötödik lakás szubstandard), elsősorban az ország gazdasági szempontból hátrányos helyzetú területein. ${ }^{9}$

Becslések szerint hazánkban 2-3 millió embert érint a lakhatási szegénység, vagyis ezek az emberek lakásminőségi, energiahatékonysági, megfizethetőségi, területi, illetve jogi szempontból az átlagosnál rosszabb, kiszolgáltatottabb helyzetű háztartásban élnek. ${ }^{10}$ További problémát jelent, hogy a súlyos lakhatási deprivációban élók magas, 15\%-os aránya 2007 és 2017 között lényegileg nem változott, ami

\footnotetext{
'Szubstandard a lakás, amelyre érvényes a következő feltételek valamelyike: nincs WC vagy fürdőszoba; nincs szennyvízelvezető-csatorna; a fal vályogból épült alapozás nélkül; nincs vezetékes víz. Szubstandard a lakás akkor is, ha a lakásban nincs konyha és a teljes alapterület 50 m² vagy annál kevesebb, illetve a lakás csak egy $12 \mathrm{~m}^{2}$-nél kisebb szobával rendelkezik. http://www.ksh.hu/docs/hun/xftp/idoszaki/pdf/miben elunk15 2.pdf. Elérve: 2020. 04. 06.
} 
az Európai Uniós átlag háromszorosa, ráadásul a 18 év alattiak érintettsége ennél is magasabb, 25\% körülii,10

A lakhatási deprivációs tényezők közé tartoznak:

- A lakásminőség egyes jellemzői: hazai viszonylatban a túl sötétnek tartott lakások jelentik a leggyakoribb gondot.

- A túlzsúfoltság: a KSH 2015-ös lakásfelmérése szerint a lakások 6,9\%-át, nagyjából 4 millió embert érint ez a probléma, köztük a legtöbben alacsony státuszú, gyermekes családokba tartoznak.

- A nem megfelelő lakásszerkezeti körülmények (pl. beázó tető, penészes falak, korhadó vagy vetemedő nyílászárók stb.): 2016-os adatok szerint az ország lakosai közül minden negyedik (26,7\%, 2,6 millió ember) él olyan lakásban, amely beázik, vizesedik vagy penészesedik. A szegénységi küszöb alatt élők közül minden másodikat érint ez a probléma (46,6\%). Beázó, vizes, penészes lakásban 540500 gyermek él.

- A lakás környezetét érintő negatív külső hatások (bünözés, zajártalom, környezetszennyezés): ezek közül az utóbbi okozza hazánkban a legföbb problémát. ${ }^{11}$

\section{MÓDSZERTAN}

A téma áttekintéséhez a PubMed adatbázisban végeztünk szakirodalom-kutatást. A fellelt angol és magyar nyelvű közlemények közül azok kerültek be az elemzésbe, amelyek európai vagy észak-amerikai populációra vonatkoztak, és 2000 után jelentek meg.

A keresés során az alábbi kulcsszavakat használtuk: „housing”, „built environment”, „neighborhood environment”, „living environment”, minden esetben párosítva a "mental health” kulcsszóval. Az evidenciák szintjeit figyelembe véve a fellelt közlemények közül elsősorban a metaanalíziseket és szisztematikus áttekintéseket, másodsorban a randomizált kontrollált vizsgálatokat és kohorszvizsgálatokat vettük górcső alá.
Minden a lefutatott keresések során talált szakirodalmat áttekintettünk. Első körben azt vizsgáltuk, hogy megfelelnek-e a meghatározott kritériumoknak, ezek után témánként csak azon irodalmakat vettük figyelembe, amelyek a témában releváns következtetéseket vontak le, akár igazolták, akár nem a feltételezett kapcsolatokat a mentális egészségi állapot és a bemutatott tényezők között. Az azonos kérdéseket vizsgáló elemzések közül, ha az eredményeik egy irányba mutattak, a magasabb evidencia szintű tanulmány került be az összefoglalóba.

\section{EREDMÉNYEK}

\section{Lakásviszonyok és egészségi mutatók}

Mind a szűkebb (otthon, lakás), mind a tágabb lakókörnyezetünk (környék) különböző - közvetlen és közvetett, testi és lelki - mechanizmusokon keresztül hatással van egészségünkre, befolyásolja rizikóés egészségmagatartásunk alakulását, a különböző betegségek és pszichoszomatikus tünetek megjelenését és fennmaradását. ${ }^{12}$ Ráadásul az otthon érzelmileg és kognitív szempontból egyaránt kiemelt környezetet jelent, amelynek szerepe - épp e kitüntetett jelentősége miatt - a mentális egészség szempontjából is alapvető. ${ }^{13}$ Innen egyből adódik a kérdés, vajon hogyan írhatók le a megfelelő (egészséges) lakásviszonyok? Az 1996-os isztambuli Habitat konferencián (Second United Nations Conference on Human Settlements) elfogadott meghatározás szerint: „A megfelelő lakóhely többet jelent, mint tetőt valaki feje felett. Beletartozik a megfelelő magánélet; a megfelelő tér; a fizikai megközelíthetőség; a megfelelő biztonság; az ottlakás biztonsága; a strukturális stabilitás és tartósság; a megfelelő világítás, fútés és szellőzés; a megfelelő alapvető infrastruktúra, úgymint vízellátás, szaniter és szennyvízkezelő létesítmények; a megfelelő környezet-minőség és egészséghez kapcsolódó tényezők; és a megfelelő és megközelíthető földrajzi elhelyezkedés a munkavégzés és alapvető intézmények szempontjából: és mindez megengedhető áron kell elérhető legyen."14 (1.o.)

\footnotetext{
ii A lakhatási körülmények szempontjából súlyos deprivációnak azt tekintjük, ha a túlzsúfolt lakásban olyan lakásminőségi és -szerkezeti problémák is jelen vannak, mint a beázó tető, a mosdási lehetőség, illetve a beltéri vécéhasználat lehetőségének hiánya, vagy a túl sötét lakóegység. Forrás: https://habitat.hu/sites/lakhatasi-jelentes/wp-content/uploads/sites/5/2019/11/hfhh lakhatasi jelentes 2019.pdf Elérve: 2020. 04. 02.
} 
Az Egészségügyi Világszervezet (World Health Organization, WHO) 2002-2003 között vizsgálta a lakásviszonyok és az egészségi állapot közötti összefüggéseket nyolc európai nagyvárosban, köztük Budapesten is. A LARES (Large Analysis and Review of European Housing and Health) felmérés célja a lakásállomány minőségének áttekintése és értékelése mellett az volt, hogy bővüljenek a lakhatási körülmények egészségre, valamint a mentális és fizikai jóllétre gyakorolt hatásaira vonatkozó ismereteink. A 3373 háztartásban élő, összesen 8519 lakó adatait tartalmazó felmérés eredményei szerint összefüggés mutatható ki az egészségi állapot önbecslése és a lakók által becsült lakásminőség között, de ugyanígy a kutatók által kidolgozott lakásminőségi mutató értéke (ház fizikai állapota, pl. ablakok, ajtók, falak stb. állapota) és az abban élők egészségi mutatói között is. ${ }^{15}$

A megfelelő otthon jelentős pszichoszociális előnyökkel jár az ott élők számára a biztonság, nyugalom és stabilitás megteremtése által. Különösen az idősebb korosztály számára rendkívül fontos a kontroll és biztonság érzete, amelyet otthonuk nyújt. A fenti előnyök vonatkozásában nincs érdemi különbség a saját tulajdonú és a bérelt lakások között, de a lakásminőség befolyásoló hatása jelentős: az alacsonyabb lakásminőség a biztonság és kontroll csökkent érzetével jár együtt, vagyis az otthon ezekben a helyzetekben kevésbé tud biztonságos helyként (safe place) múködni. Azok a lakások, amelyek nem nyújtanak elégséges védelmet a külvilággal szemben (legyen az külső zaj, kíváncsi tekintetek vagy illetéktelen behatolás), jelentős mértékú pszichés szenvedés forrásai lehetnek, és hozzájárulnak olyan mentális zavarok kialakulásához, mint a depresszió, szorongás, alvászavarok vagy paranoid állapotok. ${ }^{16}$

A mentális egészség vonatkozásában a LARES kutatói megállapították, hogy a lakhatás egyes jellemzői szerepet játszanak a depresszió vagy a szorongás kialakulásában, a tünetek fenntartásában vagy felerősítésében is. Ilyen tényező lehet a természetes fény hiánya, amely 60\%-kal, az ablakokból nyíló megfelelő kilátás hiánya vagy a zajterhelés, amelyek 40-40\%-kal növelik a betegség kialakulásának eséIyét. (Utóbbi azért kiemelt jelentőségú, mivel a zaj az alvás minőségét is rontja, így duplán is veszélyeztetetté tesz a hangulatzavar irányába.) Penészes és nedves lakásban 60\%-kal, míg olyan lakásban, ahol nincs biztosítva a személyes tér, 50\%-kal nagyobb valószínúséggel jelentkeznek depressziós tünetek az ott lakóknál.

A különálló konyha, a megfelelő WC és fürdőszoba hiánya, a fútés elégtelensége, a hulló vakolat a depresszió kialakulásának nagyobb kockázatával jár együtt. ${ }^{17}$

A fizikai és mentális egészség szempontjából is fontos, hogy a lakás:

- nyújtson megfelelő védelmet a külső hatásokkal szemben (zaj, vibráció, nedvesség, penészgombák, huzat, téli hideg stb.);

- biztosítson teret az egyedülléthez;

- az ott lakók szabadnak érezhessék magukat benne;

- legyen elég világos, nyújtson szép kilátást a külső környezetre;

- a közvetlen lakókörnyezetben (mint kiterjesztett élettérben) legyenek parkok, kertek, játszóterek, és azok ne legyenek kitéve vandalizmusnak. ${ }^{14}$

Az otthon elhelyezkedésénél fontos, hogy se túl távol, se túl közel ne legyen a szomszédokhoz (előbbi az elszigeteltség érzését erősíti, utóbbinál túlzottan elárasztva érezzük magunkat a közelben lakók által). A mentális egészségre pozitívan hat, ha az épületek legfeljebb négy emelet magasak, az otthon, illetve a közvetlen környezete is rendezett, nincsenek a leromlásra utaló jelek, és a lakóhely maga kényelmes és komfortos (például van melegvíz a konyhában és a fürdőben, van elegendő számú és jól szellőző mellékhelyiség). ${ }^{14}$

A lakás komfortszintje és az ott lakók mentális egészsége is összefügg: az alacsony komfortfokozattal bíró lakóhelyek megnövelik egyes szomatikus betegségek kialakulásának valószínúségét ( $p l$. nem megfelelő szellőzés az asztma, a nem megfelelő fütés és hőszigetelés légzőszervi problémák és artritisz kialakulásával hozható összefüggésbe), a krónikus betegségek pedig negatívan hatnak majd a mentális egészségre is. ${ }^{16}$

Fontos elem továbbá a lakhatással kapcsolatos kontroll érzése: akár a félelem az otthon elvesztésétől, akár az észlelt képtelenség a lakhatási körülmények megváltoztatására (például anyagi okokból) jelentős rizikófaktora lehet a szorongásos és depressziós tünetek kialakulásának. ${ }^{16}$ 
A következőkben néhány lakásminőséggel és szerkezettel kapcsolatos tényezőt tekintünk át a mentális egészség vonatkozásában.

Magas, sokemeletes házak

A sokemeletes házakban élőknél nagyobb arányban figyelhető meg szorongás, amely az emeletek számának növekedésével fokozódhat. ${ }^{9}$ Egy hazai kutatás, amely a dél-alföldi régióban a 14-21 év közötti fiatalok egészségmagatartását, pszichoszociális egészségét és lakóhely/lakástípus szerinti jellegzetességeit vizsgálta, arra az eredményre jutott, hogy a bérlakásban vagy lakótelepen élő fiatalok között többen szenvednek pszichoszomatikus és depresszív tünetektől, mint társaik. ${ }^{18}$

A lakótelepi lakások több vonatkozásban is negatívan hatnak a mentális egészségre: alapterületük általában kicsi (csak 1,8\%-uk nagyobb 80 m²-nél), ritkán tartozik hozzájuk zöldterület és jellemzően nincs elég tér biztosítva a szociális kapcsolatok kialakításához, fenntartásához: az előterek, társalgók és más közösségi terek hiányoznak. ${ }^{19,20}$ Egy amerikai kutatás szerint pl. azok a kisgyermekes nők, akik sokemeletes házakban élnek, magányosabbak, kevésbé érzik úgy, hogy befolyásolni tudják a környezetüket és életüket, pszichológiai jóllétük rosszabb. ${ }^{9}$

\section{Zsúfoltság}

Az egészséget negatívan befolyásoló környezet kapcsán felmerül a tér hiánya és a lakások kicsi volta is. ${ }^{21}$ Zsúfoltságon azt a helyzetet értjük, amikor a lakók száma meghaladja a rendelkezésre álló lakóterület kapacitását, akár a helyiségek vagy szobák számát, akár a lakás alapterületét tekintve. A háztartás zsúfoltsága ugyanakkor nemcsak az ott élő emberek számától, hanem életkoruktól, kapcsolatuktól és nemüktôl is függ, de befolyásolják egyéb tényezők is, például, ha a lakók csak a ház bizonyos helyiségeit használják, hogy csökkentsék a fütési költségeket. ${ }^{22}$

Számos prospektív és retrospektív kohorszvizsgálat eredményei igazolják, hogy a zsúfolt háztartásokban élőknél gyakrabban fordulnak elő mentális problémák (magas distressz-szint, depresszió ${ }^{21}$, alkoholabúzus, alvászavarok), mint azoknál, akik nem zsúfoltságban élnek. ${ }^{22}$
A megfelelő (saját) tér hiánya önmagában is stresszkeltő, ami negatív hatással van a társas kapcsolatokra (beleértve a házassági kapcsolatot és a szülő gyerek kapcsolatot is), ami pedig szintén rosszabb mentális egészséggel, gyermekeknél több magatartási problémával és a jóllét alacsonyabb szintjével jár együtt. ${ }^{23} \mathrm{~A}$ zsúfoltabb vagy zajosabb otthonokban élő gyermekek ugyanakkor kevésbé szenvednek el káros következményeket, ha az otthonon belül van olyan helyiség, ahol egyedül lehetnek. ${ }^{20}$

\section{Zaj}

A zaj elsődlegesen az alvást zavaró hatása miatt kap kitüntetett szerepet a lakhatással összefüggő tényezők között. Az alvászavarok leggyakoribb exogén oka a környezeti zaj, azok között is elsődleges a forgalom zaja, amelyet a szomszédból átszürődő zaj és a repülőgépek zaja követ. ${ }^{13,16} A$ forgalmas utcák közelében élők szignifikánsan gyakrabban szenvednek alvászavarban. ${ }^{16} \mathrm{Az}$ akut alvászavarok azután hatással vannak az egyén szubjektív állapotára, és a teljesítményét is befolyásolhatják. A környezeti zaj nemcsak éjszaka, de nappal is stresszt (zaklatottságot, feszültséget) okozhat, amely megnöveli a szív-érrendszeri betegségek, a migrén és a magasvérnyomás-betegség kockázatát, így közvetett és közvetlen úton egyaránt rontja a mentális egészséget. ${ }^{16} \mathrm{Az}$ állandó zaj gyakran jár együtt ingerlékenységgel és negatív érzelmi állapottal, amely a társas kapcsolatokra van negatív hatással. ${ }^{24}$ Amint az a korábbiakban említésre került, a LARES vizsgálat eredményei alapján a zaj 40\%-kal növeli a depresszió kialakulásának valószínúségét, és ha ez a zaj az alvást zavarja, az megduplázhatja a betegség kialakulásának valószínűségét.

A zaj a fentieken kívül - elsődlegesen fáradtságot és a figyelem csökkenését kiváltó hatása miatt - a háztartási balesetek növekvő gyakoriságához is hozzájárul. ${ }^{16}$

\section{Világítás, természetes fény}

A megfelelő természetes napfény és a mesterséges megvilágítás az egészséges lakás alapvető kritériumai közé tartozik. A napfény a külső környezettel való közvetlen kapcsolat érzetét kelti a bentlakókban, amely fontos az ember általános közérzete, mentális jólléte szempontjából. ${ }^{25}$ Azokban a laká- 
sokban, ahol kevesebb a természetes napfény, az ott élők gyakrabban érzik magukat lehangoltnak, fáradékonynak, és gyakrabban fordul elő körükben (szezonális) depresszió. ${ }^{21}$

A LARES vizsgálat eredményei is ezt támasztják alá, amelyek szerint a természetes fény hiánya akár 60\%-kal növelheti a depresszió valószínúségét, de jelentős a hozzájárulása a krónikus szorongás kialakulásához is. ${ }^{14}$

\section{A környezeti expozíció hatása a mentális egészségre}

Számos vizsgálat foglalkozik a közvetlen környezeti hatásoknak való kitettség és a mentális egészség kapcsolatával. A legismertebb hatások a környezeti légszennyezéshez és a rossz vízminőséghez köthetők, de sok kutatás érinti a neurológiai és a kognitív funkciók, valamint a környezeti expozíciók közötti összefüggéseket, elsősorban a nehézfémek, a növényvédő- és oldószerek vonatkozásában. ${ }^{12}$ Ugyanakkor a káros környezeti expozíciónak kitettségtől való félelem önmagában is okozhat mentális problémákat (pl. félelem, szorongás, pánikzavar, alvászavar, tehetetlenség érzése, pesszimizmus). ${ }^{26}$

\section{Légszennyezés}

Mivel az európai országokban az emberek többsége zárt térben tölti idejének nagy részét, a beltéri levegő minősége fontos egészségmeghatározó tényező; a belső térben jelen lévő mérgező anyagok hatása a mentális egészség szempontjából sem elhanyagolható. ${ }^{25} \mathrm{~A}$ radon- és azbeszt-expozíció, a gázzal főzésből, fútésből származó emissziók, valamint a környezeti dohányfüst közvetve, az általuk okozott (krónikus) szomatikus betegségeken keresztül vannak kapcsolatban a mentális egészség romlásával. ${ }^{14}$

A beltéri levegő minőségének fontos meghatározója továbbá a lakás páratartalmából adódó penészesedés, amit különböző építési paraméterek például az építőanyagok minősége-, a hőmérséklet, a szellőzés, valamint az épületben lakók viselkedése befolyásol. Közel hatezer európai felnőtt adatainak elemzése alapján elmondható, hogy már kismértékú nedvesség vagy penészesedés is a depresszió megnövekedett kockázatával jár együtt, függetlenül a lakás egyéb jellemzőitől. Háttérváltozóként két tényező azonositható: egyrészt a penészesedéssel kapcsolatos egészségi problémák (asztma, megfázás, légúti megbetegedés, fáradtság), másrészt pedig az élettér feletti kontroll elvesztésének észlelése. ${ }^{27} \mathrm{~A}$ penészesedés emellett okozhat depressziót, kimerültséget, koncentrálási nehézségeket, és általában véve negatív módon hat az ott lakók hangulatára. ${ }^{28}$

Nem csak a belső térben jelenlévő anyagok hozhatók kapcsolatba a mentális megbetegedésekkel: a külső térben lévő szennyezőanyagok - úgymint a kén-dioxid, a szén-dioxid, a fluor, a nitrózus gázok és a szilárd anyagok (korom, pernye, por) - jelenléte is befolyásolja mentális egészségünket. ${ }^{25}$ Egy nagymintás ( $N=552.221$ ), longitudinális svéd kohorszkutatás összefüggést mutatott ki a gyerekek és a serdülők mentális egészsége és a légszennyezés között. ${ }^{29} \mathrm{~A}$ kutatók azt találták, hogy a légszennyezés már kismértékű növekedése is összefügg a kezelt pszichiátriai zavarok számának növekedésével. Más vizsgálatok szerint az időseknél elsősorban a levegőben lévő szilárd és folyékony anyagok, a nitrogén-dioxid és az ólom növekedése felelős a depressziós tünetek kialakulásának növekvő valószínűségéért, a szén-monoxid, ólom, a finom és durva por pedig fokozhatja a demencia és a kognitív hanyatlás kialakulását. ${ }^{30,31}$ Attademo és munkatársai szerint a kadmium és az ólom magasabb koncentrációja a levegőben a skizofrénia kialakulásának is rizikófaktora lehet. ${ }^{32}$

\section{Ivóvíz-szennyezettség}

A kémiai vízminőség szempontjából a legjelentősebb problémát a határérték feletti arzéntartalom jelenti, mely hatással lehet a mentális egészségünkre. Az akut mérgezés pszichózist okozhat, míg a krónikus arzénmérgezés tünetei lehetnek a zavartság, memóriaproblémák és más kognitív deficitek. ${ }^{33} \mathrm{Az}$ arzénexpozíció gyermekkorban a memória és a tanulási képesség romlását okozza, de kapcsolatot találtak az arzénkoncentráció, valamint a felnőttkori depresszió, szorongás és alvási zavarok előfordulási gyakorisága között is. ${ }^{34}$

Másik jelentős probléma az ólomkoncentrációnak a régi ólomvezetékek használatából eredő növekedése. Az ivóvízben lévő ólom elsősorban a kisgyermekek mentális fejlődésére van negatív hatással: $10 \mu \mathrm{g} / \mathrm{dl}$ feletti vérólomtartalom szignifikánsan alacsonyabb összintelligencia pontszámmal és 
performációs IQ értékekkel jár együtt, de már nagyon alacsony expozíció $(<50 \mu \mathrm{g} / \mathrm{l})$ is okoz neurotoxikus hatásokat, és ezek a hatások (pl. az iskolai teljesítménnyel mérve) évekig fennmaradnak. ${ }^{35,36}$ Más vizsgálatok szignifikáns pozitív irányú összefüggéseket mutattak ki a vér ólomkoncentrációja és a tanárok által jelzett viselkedési problémák között, beleértve a szorongásos zavarokat, a fokozott érzelmi reaktivitást és a pervazív fejlődési zavarokat is. ${ }^{37}$ Kapcsolatot találtak továbbá a pre- és posztnatális időszakban mért vérólom-koncentráció és a felnőttkori bűncselekmények gyakorisága, valamint a gyerekkori légköri ólomszennyezettségnek kitettség és a későbbi antiszociális viselkedés előfordulása között. ${ }^{38,39}$

Említést érdemel továbbá a kutatók által leírt együttjárás egyes veszélyes anyagoknak (higany, mangán, szerves oldószerek) való kitettség és a szorongás, depresszió, ingerlékenység kialakulása és a csökkent koncentrációs képesség között. ${ }^{12}$

Az egészségünk szempontjából nemcsak a lakás egyes jellemzői bírnak befolyásoló szereppel, mivel annak közvetlen környezete is a kiterjesztett élettér része. A következőkben a közvetlen lakókörnyezet egyes jellemzőit tekintjük át a mentális egészség vonatkozásában.

\section{Zöld terek elérhetősége}

A zöld tér olyan területeket foglal magában, mint a természetvédelmi területek és a városokban kialakított parkok, zöld övezetek. Városi környezetben a zöld tereket célzottan rekreációs, valamint esztétikai okok miatt alakítják ki.

A zöld terek, parkok hozzáférhetősége jelentős tényező a mentális egészség szempontjából. Az Egészségügyi Világszervezet szerint a zöld terek lehetőséget biztosítanak a fizikai aktivitásra és ezen keresztül a társadalmi interakciókra, valamint a pihenésre. ${ }^{40}$ Becslések szerint a rekreációs terek hozzáférhetőségének hiányához kapcsolódó fizikai inaktivitás a halálozások 3,3\%-át teszi ki, míg a szabadban töltött idő és a közeli zöld terek megléte összefüggést mutatnak a mentális egészség mutatóival. ${ }^{41}$
A zöld terek mentális egészségre gyakorolt hatását számos tanulmány vizsgálja, amelyek jelentős része szignifikáns összefüggést talált azok hiánya és a depresszív hangulat között, míg egy dán tanulmány azt igazolta, hogy ezeknek a természetes tereknek a hozzáférhetősége pozitivan hat az életminőségre és a stressz-szintre. ${ }^{42,43} \mathrm{~A}$ természetes környezet és az abból származó ingerek (a zöld táj) anélkül kötik le a figyelmünket, hogy azért erőfeszítést kellene tennünk, így segítenek a szellemi fáradtság csökkentésében is. ${ }^{24}$

Egy holland nagymintás ( $\mathrm{N}=10000)$ vizsgálat eredményei szerint az emberek környezetében lévő zöld terek alacsony aránya összefüggést mutatott a magányosság érzésével és a társas támasz hiányával, a társadalmi-gazdasági, valamint demográfiai tényezők hatásának korrigálása után is. A zöld terek pozitívan befolyásolhatják a társadalmi tőkét azáltal, hogy egy találkozási pontot biztosítanak az ott élők számára, ami javítja a társas kapcsolatokat. ${ }^{44}$ A zöld terek kialakítását már széles körben egészséget támogató és az egészség-egyenlőtlenségeket csökkentő kezdeményezésnek tekintik - kialakításuk potenciális mentális egészségfejlesztő stratégiának bizonyulhat. ${ }^{41}$ Egy amerikai vizsgálat során philadelphiai lakosok lelki egészségét mérték fel, mielőtt és miután a lakóhelyük környékén növényekkel teli zöld tereket alakítottak ki. A kutatást végzők megállapították, hogy a zöld területek 400 méteres körzetében lakók több mint 40\%-ánál csökkent a depresszív hangulat, azokhoz képest, akik a zöldterülettől mentes környezetben laktak. A legszembetűnőbb hatás a szegénységi küszöb alatt élők körében volt megfigyelhető, ahol a zöld felületek kialakítása után a depresszió több mint 68\%-kal csökkent. ${ }^{45}$

A gyermeket nevelő családok számára az otthonnal való elégedettség fontos eleme, hogy a közelben legyen játszótér vagy olyan szabad tér, ahol a gyerekek a szabadidejüket tölthetik. Itt azonban nemcsak e helyek léte és közelsége, hanem azok biztonságossága és esztétikuma is fontos kérdés.iii, 15

\footnotetext{
iii A játszóterek szerepéről bővebben Id. Dúll A. Szabadtéri játszóterek környezetpszichológiája. In: Dúll, A. (2009). A környezetpszichológia alapkérdései: helyek, tárgyak, viselkedés. L'Harmattan, 164-172.
} 


\section{Észlelt biztonság}

A lakókörnyezet biztonságosságával összefüggő egyik gyakorta vizsgált kérdés az ott élők észlelt biztonsága, illetve annak hiánya, mely utóbbi negatívan befolyásolja az egyén életminőségét és jóllétét. ${ }^{15}$

A biztonság szubjektív észlelését elsősorban az olyan környezeti szignálok rontják, mint a környezet fizikai leromlása, a szemét vagy a graffitik (ami önmagában is alacsony szintű közösségi szellemet és gyenge közösségi kontrollt jelez), vagy olyan negatív szociális jelenségek, mint a fiatalok feltűnő viselkedésű csoportjainak megjelenése, ami aláássa a normák betartásába és betarthatóságába vetett hitet. Szintén a bizonytalanság érzetét erősíti (és így az életminőséget rontja) a bűnözéstől, bűncselekményektől való félelem, amely a lakás olyan jellemzőivel függ össze, mint a jól záródó ajtók és ablakok hiánya, tűz esetén a menekülési lehetőségek nem megfelelőnek érzékelt volta, a közösségi helyiségekben a világítás hiánya, illetve az, hogy a lakásnak nincs olyan része, ahonnan az utcai történések láthatók lennének. ${ }^{16}$

Az észlelt biztonság mértéke fontos előrejelzője a mentálisegészség-mutatóknak, alacsony szintje a depresszió megnövekedett valószínűségével jár együtt. $^{2}$

\section{Közbiztonság és bűnözés}

A lakókörnyezet vizsgálata során további fontos tényező a közbiztonság és a búnözés mértéke.

A lakókörnyezet jellemzőinek vizsgálata azt mutatja, hogy azokon a területen, ahol magasabb a közbiztonság szintje, az ott élő lakosok az életkoruktól, nemüktől függetlenül jobb általános és mentális egészségről számolnak be. ${ }^{46} \mathrm{Ha}$ a személy veszélyeztetve érzi magát és szeretteit, az önmagában is jelentős stresszforrás lehet. ${ }^{47}$

Az erőszakos búncselekmények a sérüléseken keresztül közvetlen hatással vannak a fizikai egészségre, azonban ugyanilyen fontos a bűnözés és a bűnözéstől való félelem hatása a mentális egészségre is. Több kutatás kimutatta, hogy a bűnözés, a nem megfelelő közbiztonság, valamint a szomszédokkal kapcsolatos bizalmatlanság hozzájárulhat a mentális állapot romlásához. ${ }^{48}$ Akik olyan területen élnek, ahol magas a búnözési ráta, és bizalmatlanok a szomszédjaikkal, jellemzően kerülik a társasági életet, inkább otthon maradnak, és nem ápolják a családi és baráti kapcsolataikat. Ez viszont a társas támogatás csökkenésén keresztül negatívan hat a mentális egészségre, és csökkenti a személy megküzdési erőforrásait is. ${ }^{49}$

A bűnözéstől való félelem rosszabb mentális egészséggel, csökkent fizikai aktivitással és alacsonyabb életminőséggel jár együtt. Egy brit vizsgálatban az intenzívebb félelmet mutató résztvevők esetében másfélszeres gyakorisággal fordultak elő mentális zavarok, és csaknem kétszeres valószínűséggel voltak depressziós tüneteik. A rosszabb mentálisegészség-mutatók hátterében a kevesebb testmozgás és a ritkább társas aktivitás volt azonosítható. ${ }^{50}$ A nem megfelelő lakókörnyezet - a biztonság hiánya, a rossz minőségű lakások, az elégtelen infrastrukturális lehetőségek és a környezetben található kevés hasznosítható erőforrás - stresszt okoz, ami depresszióhoz vezethet. A kedvezőtlen lakókörnyezet által kiváltott stressz fokozza az egyéni stressztényezők ( $p l$. szegénység, családi vagy munkahelyi negatív események) hatását, valamint zavarja a szociális kapcsolatok kialakulását, ami ismét növeli a depresszió kockázatát. ${ }^{47}$

A bűncselekmények csökkentése érdekében tett fejlesztések (pl. az utcai közvilágítás javítása), a többkomponensú búnmegelőzési programok, valamint a városrehabilitációs programok csökkenthetik a búnözéstől való félelmet. Azon személyek, akik nem tartják biztonságosnak a környéküket, hajlamosak fizikai aktivitásuk korlátozására is, így a bűnözés és a búnözéstől való félelem az egészségmagatartást (pl. a testmozgást) és azon keresztül a fizikai és mentális egészségi állapotot is befolyásolhatja, valamint negatívan hat a társadalmi kohézióra is. ${ }^{47,48}$ A biztonsággal kapcsolatos félelem különösen idősebb korban jár a fizikai aktivitás alacsonyabb és a depresszió magasabb szintjével. ${ }^{51}$ Azok között a gyermekek között, akik olyan helyen nőnek fel, ahol rossz a közbiztonság, és a környezetükben állandóan jelen van az erőszak, gyakrabban fordul elő kábítószerrel való visszaélés, erőszakos viselkedés, valamint mentális betegségek megjelenése, beleértve a szorongást, a depressziót és a poszttraumás stresszbetegséget. ${ }^{52}$

A közbiztonság és a mentális egészség közti kapcsolat értelmezésekor figyelembe kell venni azt a viszszacsatolási modellt is, amely szerint a bűnözéstől 
való félelem károsítja a mentális egészséget, ami azonban - a fokozott sebezhetőség és bizonytalanságérzés miatt - felerősíti a félelmet. ${ }^{53}$

A bűnözéstől való félelem tehát három lehetséges úton is hat a mentális egészségre: (1) közvetlenül, a kiváltott stressz által; (2) a fizikai aktivitás csökkentésével, amely ezután negatívan hat a mentális és fizikai egészségre; és (3) a társas kapcsolatok és a bizalom csökkentésével, amely szintén negatívan befolyásolja a mentális és fizikai egészséget egyaránt. ${ }^{53}$

\section{ÖSSZEGZÉS}

A fentiek összegzéseként elmondható, hogy a fizikai környezetünk és így az általunk elemzett lakhatási körülmények is részben direkt, részben indirekt módon hatnak a mentális egészségre. A mentális egészségre közvetlen hatást gyakorló környezeti jellemzők között szerepelnek a lakás minőségi jellemzői, a zsúfoltság, a zaj, a fény, a bel- és kültéri levegő és víz minősége, valamint a tágabb lakókörnyezet egyes jellemzői. A közvetlen hatásokon túl ugyanakkor az épített környezet közvetett módon is befolyásolhatja a mentális egészséget részben intrapszichés (pl. búnözéstől való félelem), részben pszichoszociális folyamatok (pl. társas aktivitás facilitálása vagy gátlása) révén. ${ }^{12} \mathrm{E}$ hatások és összefüggések mind pontosabb megértése segítség lehet abban, hogy a mentális egészségre ható következmények már az épített környezet megtervezésekor is súlyponti elemként szerepelhessenek. Ahogy a téma jeles kutatója, Mary Shaw megállapítja: a beruházás a lakhatásba több mint tégla és habarcs - ez az alapja a lakosság jövőbeli egészségének és jóllétének. ${ }^{54}$

\section{HIVATKOZÁSOK}

\footnotetext{
${ }^{1}$ Engel G. L. A need for a new medical model: A challenge for biomedicine. Science. 1997:;196(4286): $129-136$.

${ }^{2}$ Alegría M, NeMoyer A, Bagué IF, et al. Social determinants of mental health: Where we are and where we need to go. Curr Psychiatry Rep. 2018;20:11: 95. doi: 10.1007/s11920-018-0969-9

${ }^{3}$ Marmot M, Ryff CD, Bumpass, LL, et al. Social inequalities in health: next questions and converging evidence. Soc Sci Med. 1997;44:6:901-910. doi: 10.1016/S0277-9536(96)00194-3

${ }^{4}$ Adler NE, Boyce WT, Chesney MAet al. Socioeconomic inequalities in health: no easy solution. JAMA. 1993:269:24:3140-3145. doi:10.1001/jama.1993.03500240084031

${ }^{5}$ Adler NE, Epel ES, Castellazzo G, et al. Relationship of subjective and objective social status with psychological and physiological functioning: Preliminary data in healthy, White women. Health Psychol. 2000;19:6:586. doi 10.1037/0278-6133.19.6.586

${ }^{6}$ Kopp M, Skrabski Á, Szedmák S. A testi és a lelki egészség összefüggései országos reprezentatív felmérések alapján. Demográfia. 1999;42(1-2):88-119.

${ }^{7}$ Braveman P, Egerter S, Williams DR. The social determinants of health: coming of age. Annu Rev Public Health. 2011;32:381-398. doi 10.1146/annurev-publhealth-031210-101218

${ }^{8}$ Dúll, A. (2009). A környezetpszichológia alapkérdései: helyek, tárgyak, viselkedés. L'Harmattan. 2. o.

${ }^{9}$ http://www.ksh.hu/docs/hun/xftp/idoszaki/pdf/miben elunk15.pdf (Elérve: 2020. 03. 30.)

${ }^{10}$ Habitat for Humanity Magyarország. Éves jelentés a lakhatási szegénységről 2019. https://habitat.hu/sites/lakhatasijelentes/wp-content/uploads/sites/5/2019/11/hfhh lakhatasi jelentes 2019.pdf (Elérve: 2020. 03. 23.)

${ }^{11}$ Habitat for Humanity Magyarország. Éves jelentés a lakhatási szegénységről 2016. https://habitat.hu/wp-content/uploads/2018/08/Habitat eves jelentes 2016 web 2.pdf (Elérve: 2020. 03. 23.)

${ }^{12}$ Evans GW. The Built Environment and Mental Health. Bull N Y Acad Med. 2003;80:536-555. doi 10.1093/jurban/jtg063

${ }^{13}$ Dúll A. Az otthon környezetpszichológiája.

In: Dúll, A. (2009). A környezetpszichológia alapkérdései: helyek, tárgyak, viselkedés. L'Harmattan, 88-120.

${ }^{14} \mathrm{~A}$ lakáshigiénés viszonyok és az egészség kapcsolatára vonatkozó bizonyítékok áttekintése IV. Környezet és Egészség miniszteri konferencia, Budapest, 2004. Elérve: 2020. 03. 20. http://oki.antsz.hu/documents/lakas.pdf
} 
${ }^{15}$ World Health Organization Large analysis and review of European housing and health status (LARES), 2007. http://www.euro.who.int/ data/assets/pdf file/0007/107476/lares result.pdf (Elérve: 2020. 03. 20.)

${ }^{16}$ Bonnefoy X. Inadequate housing and health: an overview. Int J Environ Pollut. 2007;30(3-4):411-429. doi: 10.1504/IJEP.2007.014819

${ }^{17}$ Rautio N, Filatova S, Lehtiniemi H, et al. Living environment and its relationship to depressive mood: a systematic review. Int J Soc Psychiatry. 2018;64(1):92-103. doi: 10.1117/0020764017744582

${ }^{18}$ Keresztes N, Pluhár Zs, Pikó B. Fiatalok életmódja és egészsége lakóhelyük tükrében.

Új Pedagógiai Szemle, 2006;6: 3647

${ }^{19}$ Egedy T. A magyar lakótelepek helyzetének értékelése. Földrajzi Értesítő XLIX. évf. 3-4. füzet, 2000;265-283.

${ }^{20}$ Evans GW, Wells NM, Moch A. Housing and mental health: a review of the evidence and a methodological and conceptual critique. J Soc Issues. 2003;59:475-500.

${ }^{21}$ Bolam B, Murphy S, Gleeson K. Place-identity and geographical inequalities in health: a qualitative study. Psychol Health. 2006;21(3):399-420. doi 10.1080/14768320500286526

${ }^{22}$ World Health Organization. WHO housing and health guidelines. 2018. https://apps.who.int/iris/bitstream/handle/10665/276001/9789241550376-eng.pdf (Elérve: 2020. 03. 10.)

${ }^{23}$ Solari CD, Mare RD. Housing crowding effects on children's wellbeing. Social science research, 2012;41(2): 464-476. doi:10.1016/j.ssresearch.2011.09.012

${ }^{24}$ Sullivan WC, Chang CY. Mental health and the built environment. In Making healthy places Island Press. 2011;106-116.

${ }^{25}$ Rudnai P. Lakás és egészség. Budapest: Országos Környezetegészségügyi Intézet, 2007.

${ }^{26}$ Edelstein MR. Contamination: the invisible built environment. In: Bechtel RB, Churchman A, eds. The Handbook of Environmental Psychology. 2nd ed. New York, Wiley. 2002;559-588.

${ }^{27}$ Shenassa ED, Daskalakis C, Liebhaber A, et al. Dampness and mold in the home and depression: an examination of mold-related illness and perceived control of one's home as possible depression pathways. Am J Public Health Nations Health. 2007;97(10):1893-1899. doi:10.2105/AJPH.2006.093773

${ }^{28}$ Moriske HJ, Szewzyk R, Leonidas M. Mould Guide - Guide for the prevention, investigation, evaluation and remediation of indoor mould growth. Newsletter No. 32, WHO Collaborating Centre for Air Quality Management and Air Pollution Control. 2003;2-6.

${ }^{29}$ Oudin A, Bråbäck L, Åström DO, et al. Association between neighbourhood air pollution concentrations and dispensed medication for psychiatric disorders in a large longitudinal cohort of Swedish children and adolescents. BMJ open. 2016;6(6):010004. doi 10.1136/bmjopen-2015-010004

${ }^{30} \mathrm{Lim}$ SS, Vos T, Flaxman AD, et al. A comparative risk assessment of burden of disease and injury attributable to 67 risk factors and risk factor clusters in 21 regions, 1990-2010: a systematic analysis for the Global Burden of Disease Study 2010 Lancet. 2013;381:9874:1276 https://doi.org/10.1016/S0140-6736(12)61766-8

${ }^{31}$ Killin LO, Starr JM, Shiue IJ, et al. Environmental risk factors or dementia: a systematic review. BMC geriatrics. 2016;16(1):1-28. doi 10.1186/s12877-016-0342-y

${ }^{32}$ Attademo L, Bernardini F. Air pollution and urbanicity: common risk factors for dementia and schizophrenia? Lancet Planet Health. 2017;1(3):90-91. doi 10.1016/S2542-5196(17)30042-6

${ }^{33}$ Ratnaike RN. Acute and chronic arsenic toxicity. Postgrad Med J. 2003;79(933):391-396.

${ }^{34}$ Tyler CR, Allan AM. The effects of arsenic exposure on neurological and cognitive dysfunction in human and rodent studies: a review. Curr Environ Health Rep. 2014;1(2):132-147. doi 10.1007/s40572-014-0012-1

${ }^{35}$ Jusko TA, Henderson Jr CR, et al. Blood lead concentrations $<10 \mu \mathrm{g} / \mathrm{dL}$ and child intelligence at 6 years of age. Environ Health Perspect. 2008;116(2):243-248. doi 10.1289/ehp.10424

${ }^{36}$ Skerfving $\mathrm{S}$, Löfmark L, Lundh T, et al. Late effects of low blood lead concentrations in children on school performance and cognitive functions. Neurotoxicology. 2015;49:114-120. doi 10.1016/j.neuro.2015.05.009

${ }^{37}$ Liu J, Liu X, Wang W, et al. Blood lead concentrations and children's behavioral and emotional problems: a cohort study. JAMA pediatrics. 2014;168(8):737-745. doi:10.1001/jamapediatrics.2014.332.

${ }^{38}$ Wright JP, Dietrich KN, Ris MD, et al. Association of prenatal and childhood blood lead concentrations with criminal arrests in early adulthood. PLoS medicine. 2008;5(5). doi 10.1371/journal.pmed.0050101

${ }^{39}$ Taylor MP, Forbes MK, Opeskin B, et al. The relationship between atmospheric lead emissions and aggressive crime: an ecological study. Environmental health. 2016;15(1):23. doi 10.1186/s12940-016-0122-3

${ }^{40}$ Word Health Organisation (WHO) 2016. Urban green spaces and health. Copenhagen: WHO Regional Office for Europe http://www.euro.who.int/ data/assets/pdf file/0005/321971/Urban-green-spaces-and-health-review-evidence.pdf?ua=1 (Elérve: 2020. 03. 05.) 


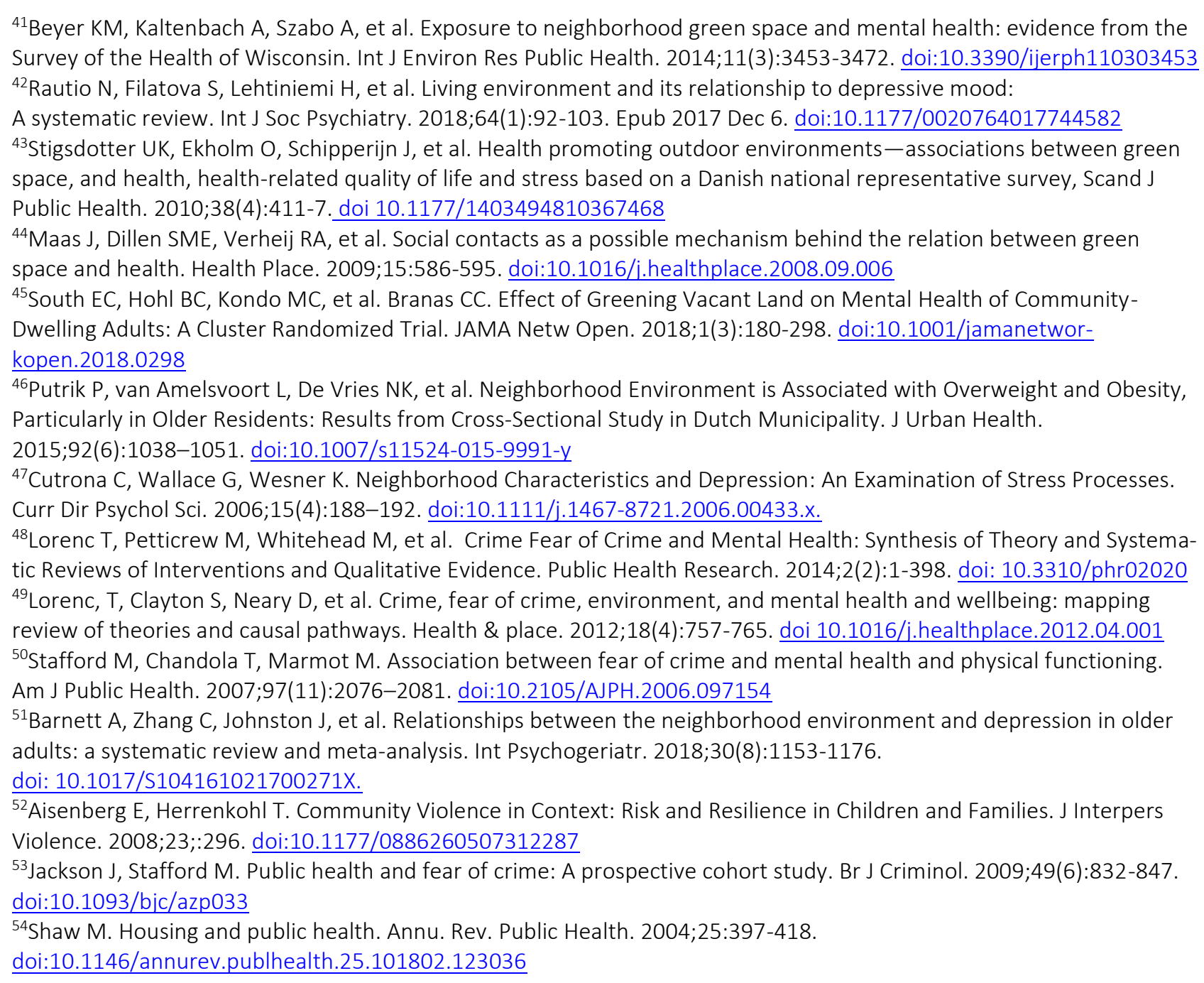

